Article

\title{
Prevalence of Aggregatibacter actinomycetemcomitans and Periodontal Findings among 14 to 15-Year Old Danish Adolescents: A Descriptive Cross-Sectional Study
}

\author{
Anne Birkeholm Jensen ${ }^{1,2}$, Flemming Isidor ${ }^{3,+}$, Marianne Lund ${ }^{4}$, Michael Væth ${ }^{5}$, \\ Anders Johansson ${ }^{6}$ (D), Niels Nørskov Lauritsen ${ }^{7}$ (D) and Dorte Haubek ${ }^{1, *(D)}$ \\ 1 Section for Pediatric Dentistry, Department of Dentistry and Oral Health, Health, Aarhus University, \\ 8000 Aarhus, Denmark; abj@dent.au.dk \\ 2 The Municipality of Aarhus, 8000 Aarhus, Denmark \\ 3 Section for Prosthetic Dentistry, Department of Dentistry and Oral Health, Health, Aarhus University, \\ 8000 Aarhus, Denmark \\ 4 Department of Clinical Microbiology, Aarhus University Hospital, Skejby, 8210 Aarhus, Denmark; \\ marialun@rm.dk \\ 5 Department of Public Health, Aarhus University, 8000 Aarhus, Denmark; vaeth@ph.au.dk \\ 6 Divison of Molecular Periodontology, Department of Odontology, Faculty of Medicine and Odontology, \\ Umea University, 90187 Umea, Sweden; anders.p.johansson@umu.se \\ 7 Department of Clinical Microbiology, Odense University Hospital, 5000 Odense, Denmark; nielnoer@rm.dk \\ * Correspondence: dorte.haubek@dent.au.dk; Tel.: +45-21-685-848 \\ + Deceased.
}

Received: 5 October 2020; Accepted: 11 December 2020; Published: 16 December 2020

\begin{abstract}
Aggregatibacter actinomycetemcomitans $(A a)$ is a keystone pathogen associated with periodontitis in adolescents. The knowledge on the prevalence of $A a$ and periodontitis among adolescents in Northern Europe is sparse. A total of 525 14- to 15-year-old adolescents from the municipality of Aarhus, Denmark, underwent a full-mouth clinical examination. Plaque score (PS), bleeding on probing (BOP), probing pocket depth (PPD), and clinical attachment loss (CAL) were recorded. Subgingival plaque samples (SPS) and stimulated saliva samples (SSS) were collected and analyzed for the presence of JP2 and non-JP2 genotypes of Aa using real-time PCR. A total of $70(13.3 \%)$ individuals were positive for $A a$, with 17 found in SPS, 19 in SSS, and 35 in both. The highly leukotoxic JP2 genotype of $A a$ was not detected. The individuals positive for $A a$ in both SPS and SSS had poorer periodontal outcomes (PPD and CAL) than individuals without $A a$ and individuals carrying $A a$ in either SPS or SSS only. In conclusion, 13\% of 14- to 15-year-old Danish adolescents were positive for $A a$, and the presence of $A a$ in both SPS and SSS was associated with poorer periodontal outcomes.
\end{abstract}

Keywords: periodontitis; JP2 genotype; periodontal outcome; A. actinomycetemcomitans; saliva sample; subgingival plaque sample; leukotoxin

\section{Introduction}

The facultative anaerobic Gram-negative rod Aggregatibacter actinomycetemcomitans is recognized as a keystone pathogenic bacterium involved in the pathogenesis of periodontitis, especially in young individuals [1], and the highly leukotoxic JP2 genotype of A. actinomycetemcomitans has been reported to significantly increase the risk of developing clinical attachment loss early in life [2-4]. The JP2 genotype of A. actinomycetemcomitans frequently occurs in young individuals living in 
Northwest Africa [5], and the prevalence of different genotypes of A. actinomycetemcomitans is reported to depend on geography [6,7]. A considerable amount of research has been done on the prevalence of $A$. actinomycetemcomitans and periodontal disease in African, American, Asian, and European countries [3,8-21], but studies undertaken in Northern European countries on this topic are sparse [22-24]. Demographics in many European countries are changing due to human migration. Therefore, the occurrence of $A$. actinomycetemcomitans and the prevalence of periodontal disease are interesting topics to study. The association between the carrier status of $A$. actinomycetemcomitans and development of periodontal disease could be different in Northern European populations compared to, e.g., African populations due to general health status, genetics, accessibility to dental care, and oral hygiene habits. Surprisingly, a study of Swedish periodontitis patients reported 30\% A. actinomycetemcomitans carriers among diseased individuals [23]. Furthermore, the detection of the JP2 genotype of $A$. actinomycetemcomitans in Caucasian individuals was reported on [23]. Interestingly, in addition to the JP2 genotype, other relatively high-leukotoxic genotypes with various leukotoxin promoter modifications were detected in this population [25]. Hence, additional population-based research on the prevalence of $A$. actinomycetemcomitans, and especially the highly leukotoxic genotypes of $A$. actinomycetemcomitans, is needed in Northern Europe.

The aim of this study was to describe the presence of the periodontal keystone pathogen A. actinomycetemcomitans in a Danish adolescent population, measured in subgingival plaque and in stimulated saliva. Groups defined by carrier status of $A$. actinomycetemcomitans were generated, described, and analyzed according to periodontal outcomes.

\section{Results}

\subsection{Study Population}

With written consent, a total of 525 individuals agreed to participate in the present study. The distribution between genders was even, with participation of 260 boys and 261 girls (one individual did not answer the questionnaire, two did not specify their gender, and one individual provided one biological sample only). Three individuals reported having diabetes. Five hundred and eight $(96.7 \%)$ defined themselves as healthy, $64(12.2 \%)$ had a daily consumption of various types of medicine, and 29 $(5.5 \%)$ of the participants had an intake of antibiotics within the last three months. Twenty $(3.8 \%)$ defined themselves as smokers.

\subsection{Carrier Status of A. actinomycetemcomitans}

Seventy (13.3\%) individuals were positive for A. actinomycetemcomitans in either subgingival plaque, in stimulated saliva, or in both. Fifty-one $(9.7 \%)$ and $54(10.2 \%)$ were positive in subgingival plaque and stimulated saliva, respectively. Of these, 35 were positive in both samples. Seventeen were positive in subgingival plaque samples only, and 19 in stimulated saliva samples only (Figure 1).

The JP2 genotype of A. actinomycetemcomitans was not detected in the present study population. No difference was found between genders according to carrier status of A. actinomycetemcomitans $(p>0.05)$.

The number of individuals positive for A. actinomycetemcomitans according to the districts in the municipality of Aarhus is shown in Figure 2. The highest amount of A. actinomycetemcomitans -positive individuals $(n=21)$ was found in district 3 , and the lowest number of A. actinomycetemcomitans -positive individuals $(n=3)$ was found in district 1.

Table 1 lists the demography of the districts according to ethnic background (data obtained from citizen data from the municipality of Aarhus) [26]. District 1 had the highest number of individuals with a Danish ethnic background (93.9\%), and district 3 had the lowest number of individuals with a Danish ethnic background (59.4\%). The percentage of individuals positive for A. actinomycetemcomitans in each district, adjusted according to the size of the districts in relation to the size of the municipality, showed the same pattern. The relative percentage of A. actinomycetemcomitans-positive individuals was $4.3 \%$, 
$15.7 \%, 30.0 \%, 17.1 \%, 21.4 \%$, and $11.4 \%$ from districts 1 to 6 , respectively. The difference in prevalence of $A$. actinomycetemcomitans between the districts was statistically significant $(p<0.05)$.

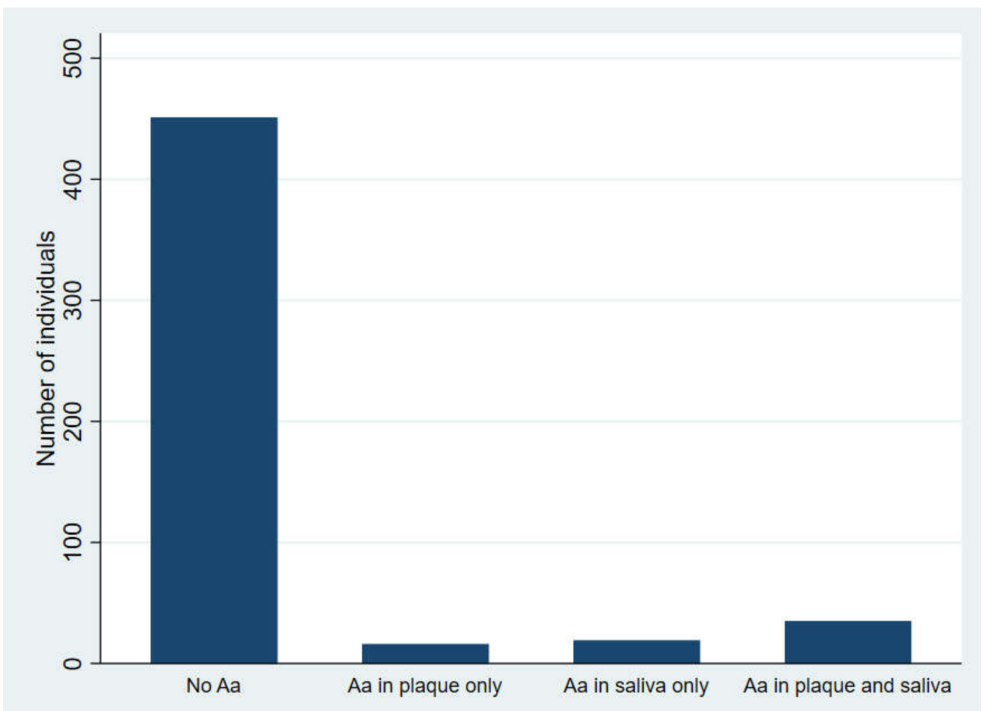

Figure 1. Distribution of participants according to carrier status of A. actinomycetemcomitans (Aa).

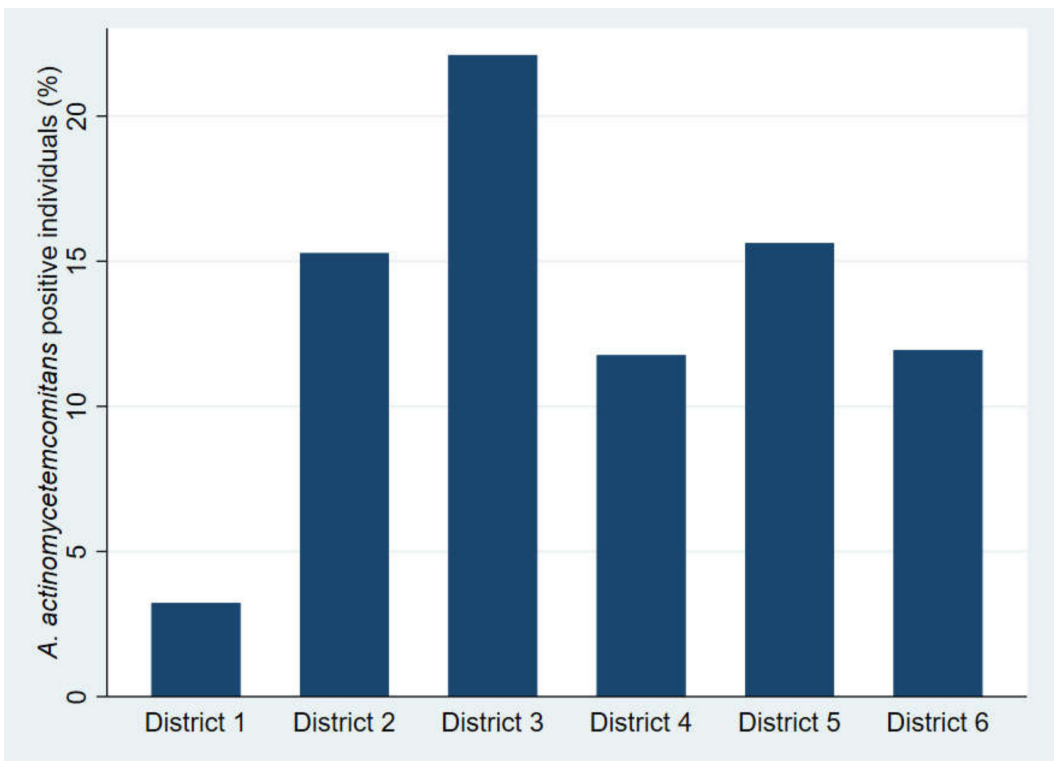

Figure 2. The number of individuals positive for A. actinomycetemcomitans $(A a)$ according to the districts of the municipality of Aarhus.

Table 1. Demographic characteristics of the six districts of the municipality of Aarhus.

\begin{tabular}{cccc}
\hline $\begin{array}{c}\text { No. of District of } \\
\text { Municipality of Aarhus, } \\
\text { Denmark }\end{array}$ & No. of Participants (\%) & $\begin{array}{c}\text { District Size According to the Total } \\
\text { no. of Individuals Born in Year 2003 } \\
\text { in the Municipality (\%) }\end{array}$ & $\begin{array}{c}\text { Proportion of Individuals } \\
\text { with a Danish Ethnic } \\
\text { Background (\%) }\end{array}$ \\
\hline 1 & $93(17.7)$ & 16.9 & 93.9 \\
2 & $72(13.7)$ & 13.9 & 76.9 \\
3 & $95(18.1)$ & 18.0 & 59.4 \\
4 & $102(19.4)$ & 17.7 & 90.4 \\
5 & $96(18.3)$ & 18.5 & 75.0 \\
6 & $67(12.7)$ & 14.9 & 84.0 \\
\hline
\end{tabular}




\subsection{Periodontal Outcomes of the Participants According to A. actinomycetemcomitans-Carrier Status}

Data on plaque scores (PS), bleeding on probing (BOP), periodontal probing depth (PPD), and interdental clinical attachment loss (CAL) scores according to the carrier status of A. actinomycetemcomitans are shown in Tables 2 and 3. In the group of individuals positive for A. actinomycetemcomitans in subgingival plaque and/or stimulated saliva, there was statistically significantly more individuals having PPD $\geq 4 \mathrm{~mm}$ and interdental CAL $\geq 2 \mathrm{~mm}$ than in the group of individuals negative for A. actinomycetemcomitans (Table 2).

Table 2. Periodontal outcomes of the group of individuals positive for A. actinomycetemcomitans (Aa) and the group of individuals without $A$. actinomycetemcomitans.

\begin{tabular}{|c|c|c|c|}
\hline Periodontal Outcomes & $\begin{array}{l}\text { Individuals Positive for } A a \\
\qquad(n=70)\end{array}$ & $\begin{array}{l}\text { Individuals with no } A a \\
\qquad(n=455)\end{array}$ & Total $(n=525)$ \\
\hline $\begin{array}{l}\text { No. of individuals with } \\
\text { PS }^{1}>20 \%(\%)\end{array}$ & $54(77.1)$ & 327 (71.9) & $381(72.6)$ \\
\hline $\begin{array}{l}\text { No. of individuals with } \\
\text { BOP }^{2}>10 \%(\%)\end{array}$ & $66(94.3)$ & $431(94.6)$ & 497 (94.7) \\
\hline $\begin{array}{c}\text { No. of individuals with } \text { PPD }^{3} \geq \\
4 \mathrm{~mm}(\%)\end{array}$ & $26(37.1)^{*}$ & $83(18.2)^{*}$ & $109(20.0)$ \\
\hline $\begin{array}{l}\text { No. of individuals with interdental } \\
\text { CAL }^{4} \geq 2 \mathrm{~mm}(\%)\end{array}$ & $4(5.7)^{*}$ & $5(1.1) *$ & $9(1.7)$ \\
\hline
\end{tabular}

* Statistical significance between groups $(p<0.05) .{ }^{1}$ plaque scores, ${ }^{2}$ bleeding on probing, ${ }^{3}$ periodontal probing depth, ${ }^{4}$ clinical attachment loss.

The group of individuals without $A$. actinomycetemcomitans consisted of a statistically significantly lower percentage of individuals having PPD $\geq 4 \mathrm{~mm}$ and interdental CAL $\geq 2 \mathrm{~mm}$ than the other groups presented in Table 3. The group of individuals positive for A. actinomycetemcomitans in both subgingival plaque and stimulated saliva consisted of a statistically significantly higher percentage of individuals with PPD $\geq 4 \mathrm{~mm}$ and CAL $\geq 2 \mathrm{~mm}$ (Table 3).

The group of individuals positive for A. actinomycetemcomitans in stimulated saliva only showed the lowest percentage of individuals with PS $>20 \%$, BOP $>10 \%$, and interdental CAL $\geq 2 \mathrm{~mm}$ (Table 3 ). However, the differences were not statistically significant (Table 3). 
Table 3. Periodontal outcomes according to carrier status of A. actinomycetemcomitans ( $A a)$.

\begin{tabular}{|c|c|c|c|c|c|c|}
\hline Periodontal Outcomes & $\begin{array}{l}\text { Individuals Positive for } \\
\text { Aa in Subgingival } \\
\text { Plaque }(n=51)\end{array}$ & $\begin{array}{l}\text { Individuals Positive } \\
\text { for } A a \text { in Stimulated } \\
\text { Saliva }(n=54)\end{array}$ & $\begin{array}{c}\text { Individuals Positive for } \\
A a \text { in Subgingival Plaque } \\
\text { only }(n=16)\end{array}$ & $\begin{array}{l}\text { Individuals Positive } \\
\text { for } A a \text { in Saliva only } \\
\qquad(n=19)\end{array}$ & $\begin{array}{c}\text { Individuals Positive for } A a \text { in } \\
\text { both Saliva and Subgingival } \\
\text { Plaque }(n=35)\end{array}$ & $\begin{array}{l}\text { Individuals with } \\
\text { no } A a(n=455)\end{array}$ \\
\hline $\begin{array}{l}\text { No. of individuals with } \\
\text { PS }^{1}>20 \%(\%)\end{array}$ & $44(86.3)^{*}$ & $42(77.8)$ & $12(75.0)$ & $10(52.6)$ & $32(91.4) *$ & 327 (71.9) \\
\hline $\begin{array}{l}\text { No. of individuals with } \\
\text { BOP }^{2}>10 \%(\%)\end{array}$ & $50(98.0)$ & $51(94.4)$ & $15(93.6)$ & $16(84.2)$ & $35(100)$ & $431(94.6)$ \\
\hline $\begin{array}{l}\text { No. of individuals with } \\
\text { PPD }^{3} \geq 4 \mathrm{~mm}(\%)\end{array}$ & $20(39.2) *$ & $22(40.7)^{*}$ & $4(25.0)$ & $6(31.6)$ & $16(45.7)^{*}$ & $83(18.2) *$ \\
\hline $\begin{array}{l}\text { No. of individuals with } \\
\text { interdental } \mathrm{CAL}^{4} \geq 2 \mathrm{~mm} \text { (\%) }\end{array}$ & $4(7.8)^{*}$ & $3(5.6)^{*}$ & $1(6.3)$ & $0(0.0)$ & $3(8.6) *$ & $5(1.1)^{*}$ \\
\hline
\end{tabular}

Statistical significance between groups $(p<0.05) .{ }^{1}$ plaque scores,${ }^{2}$ bleeding on probing, ${ }^{3}$ periodontal probing depth,${ }^{4}$ clinical attachment loss. 


\section{Discussion}

A. actinomycetemcomitans may be a causative agent in periodontal disease and in non-oral diseases, such as infectious endocarditis, various types of abscesses, bacteremia, osteomyelitis, skin infections, and urinary tract infections [27]. In the present study, we report a prevalence of $13 \%$ A. actinomycetemcomitans-carriers in a 14- to 15-year-old adolescent population in Denmark, but the highly leukotoxic JP2 genotype strain of A. actinomycetemcomitans was not detected. These results suggest an association between being a carrier of A. actinomycetemcomitans in both subgingival plaque and stimulated saliva and having poorer periodontal health.

The prevalence of A. actinomycetemcomitans is high in Asian and African populations, but is considerably lower in Europe [2,3,8-21,28,29]. The results of the present study, with a prevalence of $13 \%$ A. actinomycetemcomitans-carriers, defined as individuals positive for A. actinomycetemcomitans in subgingival plaque, stimulated saliva, or in both, are comparable to previous findings in European populations $[9,11,13,21,24,29]$. Alaluusua and co-workers reported $13 \%$ of their population of Finnish individuals to be positive for A. actinomycetemcomitans [29], and the prevalences found in Switzerland and Italy are $20 \%$ and $16 \%$, respectively $[9,14]$. Belstrøm and co-workers reported a very low occurrence of A. actinomycetemcomitans (under 3\%) among Danish adult individuals in a case-control study, including both healthy and diseased individuals [22]. A. actinomycetemcomitans is a stabile colonizer [30-33] found more often in young individuals than in adults [34], and the association with periodontitis is primarily reported in the young age groups [2-4]. These facts might explain the difference between the results of the present study and the study conducted by Belstrøm and co-workers [22].

District 3 accounted for the highest prevalence of A. actinomycetemcomitans (Figure 2), and district 3 represented the part of the municipality with the highest proportion of individuals with a non-Danish ethnic background (Table 1). Other researchers have reported the same tendency $[4,6]$. However, the proportion of individuals with a non-Danish ethnic background is higher in the municipality of Aarhus compared to the general demographic picture in Denmark [35], and the actual prevalence of A. actinomycetemcomitans in Denmark may be lower than reported here.

In accordance with previous studies, we found an association between being positive for A. actinomycetemcomitans and having poorer periodontal health outcomes (Tables 2 and 3) [2-4]. The association was primarily found in the group that was positive for A. actinomycetemcomitans in subgingival plaque and/or stimulated saliva, and in the group with no A. actinomycetemcomitans (Tables 2 and 3). These findings may indicate that a pronounced occurrence of A. actinomycetemcomitans in an individual (with detection of A. actinomycetemcomitans in both subgingival plaque and stimulated saliva) is associated with poorer periodontal health outcomes. However, due to the study being cross-sectional, we cannot conclude whether A. actinomycetemcomitans is part of the pathogenesis leading to poorer periodontal health outcomes or if the presence of A. actinomycetemcomitans is a consequence of disease.

The study population consisted mainly of very periodontally healthy individuals, and the proportion of individuals with a non-Danish ethnic background was higher than in the general Danish population. However, the diversity of ethnicity in the present study population represented the adolescent population of the municipality of Aarhus (Table 1).

The bacterial load was not quantified, in contrast to what has been done by other researchers $[9,18,36,37]$. Still, we used valid sampling methods (pooled subgingival plaque samples and stimulated saliva samples) and sensitive detection methods (real-time PCR), which have also been used in other studies [38-41]. Therefore, we are confident in reporting a prevalence of $13 \%$ A. actinomycetemcomitans-carriers in the present study. Finally, due to the study design and the participants, the calibration process of the examiner was performed on healthy individuals, and it is well known that it is easier to reproduce a measurement of "zero".

Despite the limitations addressed above, the findings presented here justify further research on A. actinomycetemcomitans and its implication in a Danish adolescent population. The JP2 genotype 
of $A$. actinomycetemcomitans was not detected in the present study population. However, studies on the prevalence of A. actinomycetemcomitans are still of importance due to the association of this microorganism with periodontitis and non-oral diseases [27]. The presence of $A$. actinomycetemcomitans among primarily healthy Danish adolescents is indisputable, and the results of the present study suggest a positive association between being positive for A. actinomycetemcomitans in both subgingival plaque and stimulated saliva and having poorer periodontal health outcomes in the Danish population.

\section{Materials and Methods}

\subsection{Study Population}

In the year 2018, 3165 14- to 15-year-old individuals were affiliated with the dental clinics of the municipality of Aarhus, Denmark. With the aim of examining a $25 \%$ sample of the 14 - to 15 -year-old individuals affiliated with the municipality of Aarhus, 1145 (1/3 of the population of 14- to 15-year-olds) were randomly selected for enrolment in the present cross-sectional study. The criteria for participation were Danish citizenship, being born in the year 2003, and having had no prior dental examination during the 2018 calendar year. Out of the 1145 selected individuals, 220 (19.2\%) adolescents had unintentionally already had their routinely and mandatory clinical examinations carried out by the clinical staff of the municipality before enrolment. Therefore, $917(80.1 \%)$ of the original sample were invited to participate in the present study by email as a part of their regular invitation to the mandatory examination at the age of 15 . Of the 648 who attended the clinics for their mandatory examination, 525 (approximately $60 \%$ of the invited participants) individuals agreed to participate in the clinical study. The participants were equally distributed according to all parts of the municipality of Aarhus, comprising six districts. The demographic data concerning the ethnic background of the participants according to the districts were provided by the municipality of Aarhus [26].

The study was approved by the ethics committee of the central region of Denmark (regionmidtjylland) (1-10-72-385-17) (date of approval: 10-01-2018). Written informed consent was obtained from all participants.

\subsection{Clinical Examination}

The clinical examinations were carried out at the dental clinics in the municipality of Aarhus, with which the participants were affiliated. Six different districts and sixteen different clinics were visited during the year 2018 while carrying out the data collection process. One examiner (ABJ) carried out the clinical examinations, which included periodontal measurements of all fully erupted permanent teeth present in the oral cavity. Furthermore, all participants were asked to answer a questionnaire concerning oral hygiene habits, daily intake of medicine, smoking habits, family history of periodontal disease, and consumption of antibiotics within the last three months. All periodontal recordings were carried out on six sites per tooth (mesio-facial, facial, disto-facial, mesio-oral, oral, and disto-oral) by the use of a Deppeler ${ }^{\mathrm{TM}}$ periodontal probe (Deppeler SA, A-One Business Center, La Pièce 6,CH-1180 Rolle, Switzerland) (HH12FMS, 3-6-9-12 mm, 0.48 Ø). PS and BOP were recorded as present or not present. PPD was recorded from the gingival margin to the bottom of the periodontal pocket. CAL was recorded from the cemento-enamel junction to the bottom of the clinical periodontal pocket. All recordings were measured to the nearest millimeter.

Eleven individuals agreed to be examined subsequently within 48 hours, with the purpose of performing intra-examiner calibration. All six sites on all permanent teeth present were measured on both occasions. The calibration process was undertaken under the same conditions as the clinical examination in the clinical study. The intra-examiner reproducibility was $99.9 \%$ for PPD and $99.4 \%$ for CAL, with a margin-off-error of $\pm 1 \mathrm{~mm}$. 


\subsection{Periodontal Outcomes}

The cut-off level for having poor oral health defined by the PS and BOP was a PS $>20 \%$ of the sites and BOP $>10 \%$ of sites, respectively [42]. Only interdental CAL was used to describe the periodontal health of the individuals, because the main part of the facial and buccal clinical attachment loss was without additional PPD $>3 \mathrm{~mm}$. Only one individual presented with facial and buccal PPD $\geq 4 \mathrm{~mm}$ in addition to CAL, defining a periodontitis lesion [43]. The cut-off for a deep PPD was set at $4 \mathrm{~mm}$ or more [42,44]. According to the new consensus for the diagnosis of periodontal disease, it is important to recognize CAL at one $\mathrm{mm}$ in the diagnosis of periodontitis, so that milder cases are not overlooked [43]. However, in epidemiological studies a cut-off above one $\mathrm{mm}$ is needed because of the margin of error of $\pm 1 \mathrm{~mm}$ in measuring CAL. Therefore, we chose a cut-off of $2 \mathrm{~mm}$ in the present study in order not to miss early cases of periodontal disease in this young and otherwise healthy adolescent Danish population.

\subsection{Biological Samples}

\subsubsection{Stimulated Saliva Samples}

Stimulated saliva samples were collected as described by Ennibi and coworkers [39]. Saliva from each participant was collected before the clinical examination. The participants were asked to chew a Vivoclar Vivadent Clinical paraffin tablet (Ivoclar Vivadent AG, Schaan, Liechenstein) for one minute. Subsequently, saliva was collected in a plastic beverage cup. One $\mathrm{mL}$ of the saliva was transferred into a sterile plastic tube with a screw cap, containing $1 \mathrm{~mL}$ of saliva preservation buffer (Norgen Biotek Corporation, Schmon Parkway Thorol, ON, Canada). Samples were transported to the Department of Clinical Microbiology, Aarhus University Hospital, Skejby, Denmark, and stored at room temperature. DNA from the saliva samples was purified using a Magna Pure 96 DNA and Viral NA (Large Kit) (Roche Diagnostics, GmbH, Mannheim, Germany) on Magna Pure 96 (Roche, Germany). The bacterial DNA was stored at $-20^{\circ} \mathrm{C}$ until being analyzed by real-time polymerase chain reaction (PCR) for the detection of A. actinomycetemcomitans.

\subsubsection{Subgingival Plaque Samples}

Subgingival plaque samples were collected as one pooled subgingival sample from the mesio-facial sites of the permanent first molars before the clinical examination was carried out. Visual supragingival plaque was gently removed, and the teeth were kept dry using cotton rolls and dental suction, before a sterile paper point (Orbis Absorbent Paper Points, sterile, .04/40) (Obiliss.s, Brussels, Belgium) was placed in the periodontal pockets for 10-15 seconds. Paper points with biological samples were placed in tubes containing $1 \mathrm{~mL}$ of $0.9 \%$ saline. Samples were stored at $5{ }^{\circ} \mathrm{C}$ before being transported to the Department of Dentistry and Oral Health, Aarhus University, Aarhus, Denmark, where the samples were processed and bacterial DNA was purified. The purified bacterial DNA was stored at $-20^{\circ} \mathrm{C}$ until being analyzed by real-time PCR for the detection of A. actinomycetemcomitans.

\subsubsection{Real-Time Polymerase Chain Reaction}

The detection of A. actinomycetemcomitans was performed as described by Marín et al. with a few modifications [45]. Briefly, bacterial DNA was analyzed using probe (5'-6FAM-AGA ACT CAG AGA TGG GTT TGT GCC TTA GGG-BBO-3') and primers (forward: 5' -GAA CCT TAC CTA CTC TTG ACA TCC GAA-3' and reverse: 5' -TGC AGC ACC TGT CTC AAA GC-3') in a final volume of $15 \mu \mathrm{L}$ PCR reaction mix containing $200 \mathrm{nM}$ probe, $200 \mathrm{nM}$ of each primer, $7.5 \mu \mathrm{L}$ TaqMan Fast Advanced mastermix (Life Technologies by Thermoficher Scientific, Waltham, MA, USA), and $5 \mu \mathrm{L}$ bacterial DNA. The PCR reaction mix was placed in a clear LightCyclerß480 Multiwell Plate 96 (Roche Diagnostics GmbH, Mannheim, Germany), and the plates were loaded into a LightCyclerß480 II (Roche Diagnostics International Ltd., Rotkreuz, Switzerland). Amplification reactions consisted of $10 \mathrm{~min}$ at $95^{\circ} \mathrm{C}$, followed by 40 cycles of $15 \mathrm{~s}$ at $95^{\circ} \mathrm{C}$ and $1 \mathrm{~min}$ at $60^{\circ} \mathrm{C}$. Amplification, detection, and data analysis 
was performed with the LightCycler 480II system (Roche, Mannheim, Germany). Fluorescence was measured during the extension/annealing step of each cycle. D7SS served as the positive control, and $\mathrm{H}_{2} \mathrm{O}$ served as the negative control.

The bacterial samples positive for A. actinomycetemcomitans were additionally analyzed for the presence of the 530-bp deletion in the promoter region of the operon coding for the production of leukotoxin, characterizing the JP2 genotype of A. actinomycetemcomitans. Primers used were from Orrù et al. 2006 [41]. The real-time PCR was performed using a LightCycler instrument $₫ 480$ II (Roche Diagnostics International Ltd., Rotkreuz, Switzerland) and AmpliTaq Gold ${ }^{\mathrm{TM}}$ mastermix (appliedbiosystems by Thermo Fischer Scientific, Vilnius, Lithuania). The final volume of $20 \mu \mathrm{L}$ contained $10 \mu \mathrm{L}$ AmpliTaq Gold mastermix, 200 nM of each primer OG155 (5'- CATTCTCGGCGAAAAAACTA -3') and OG156 (5'CCCATAACCAAGCCACATAC -3’), 250 mM Syto 82 (Invitrogen by ThemoFisher Scientific), and $2 \mu \mathrm{L}$ of bacterial DNA.

The PCR program was as follows. Denaturation was done at $95^{\circ} \mathrm{C}$ for $10 \mathrm{~min}$, followed by 50 cycles of $1 \mathrm{sec}$ at $95{ }^{\circ} \mathrm{C}, 10 \mathrm{sec}$ at $49{ }^{\circ} \mathrm{C}, 40 \mathrm{sec}$ at $72{ }^{\circ} \mathrm{C}$, and $3 \mathrm{sec}$ at $74{ }^{\circ} \mathrm{C}$. A melting curve was performed for $1 \mathrm{sec}$ at $95{ }^{\circ} \mathrm{C}, 1 \mathrm{sec}$ at $45^{\circ} \mathrm{C}$, followed by rise in temperature of $0.06{ }^{\circ} \mathrm{C} / \mathrm{sec}$ up to $95^{\circ} \mathrm{C}$. Fluorescence was detected at the end of the $74{ }^{\circ} \mathrm{C}$ segment in the PCR step (single mode), and at the $45-95^{\circ} \mathrm{C}$ segment in the melting step (continuous mode) in the VIC (Hex, Joe) channel.

Melting curve peaks were observed at 74.3-74.4 for JP2 genotypes and 77.4-76.7 for non-JP2 genotypes. Strain JP2 (HK921) served as the positive control and $\mathrm{H}_{2} \mathrm{O}$ served as the negative control.

\subsection{Statistical Analysis}

The statistical analysis was performed using STATA 15 (StataCorp. 2017. Stata Statistical Software: Release 15. College Station, TX: StataCorp LLC.) and SciPy [46], which is an open source scientific tool for Pythonß(Beaverton, OR, USA). The chi squared test was used to compare the periodontal health outcomes between the groups determined according to carrier status of A. actinomycetemcomitans. A proportion test was used to analyze the statistical difference between the periodontal health outcomes of the group of individuals positive for A. actinomycetemcomitans in subgingival plaque only and the group of individuals positive for $A$. actinomycetemcomitans in stimulated saliva only. Intra-examiner reproducibility was calculated as a percentage of total agreement and with a margin of error of $\pm 1 \mathrm{~mm}$ between two measurements of PPD and CAL.

Author Contributions: Conceptualization, D.H., A.B.J., M.V. and F.I.; methodology, D.H., A.B.J., M.L., A.J., and F.I.; software, A.B.J. and M.L.; validation, A.B.J., M.L. and D.H.; formal analysis, A.B.J. and M.V.; investigation, A.B.J. and M.L.; resources, D.H. and N.N.L.; data curation, A.B.J.; writing-original draft preparation, A.B.J.; writing—review and editing, D.H., A.B.J., M.L., M.V., A.J., and N.N.L.; visualization, A.B.J.; supervision, D.H., F.I., A.J., and N.N.L.; project administration, D.H. and A.B.J.; funding acquisition, D.H. and A.B.J. All authors have read and agreed to the published version of the manuscript.

Funding: This research was funded by the University Strategic Fundings (USM-fundings) of Aarhus University, Danish Dental Association, and the Ingeborg and Leo Dannin Foundation.

Acknowledgments: We thank laboratory assistants Mette Nikolajsen and Lisbeth Ann Abildtrup for assistance in handling of the subgingival plaque samples at the Department of Dentistry and Oral Health, Aarhus University, Aarhus, Denmark. We are indebted to biomedical laboratory technician Lone Pødenphant, Department of Clinical Microbiology, Aarhus University Hospital, Skejby, Aarhus, Denmark, for important guidance and contributions in the analysis of the saliva samples. We thank Jens Heidmann (JH), Department of Dentistry and Oral Health, Aarhus University, Aarhus, Denmark, for the opportunity to use the KLIPS programme for the registration of the clinical data. We are sincerely grateful for the opportunity provided by the municipality of Aarhus for us to conduct this clinical study at the clinics of the municipality. Furthermore, we are grateful for the support and great contribution from the municipality of Aarhus by all staff members involved, among others chief dentist Mette Borum and deputy manager Henriette Hansen.

Conflicts of Interest: The authors declare no conflict of interest. 


\section{References}

1. Lamont, R.J.; Koo, H.; Hajishengallis, G. The oral microbiota: Dynamic communities and host interactions. Nat. Rev. Microbiol. 2018, 16, 745. [CrossRef] [PubMed]

2. Åberg, C.H.; Haubek, D.; Kwamin, F.; Johansson, A.; Claesson, R. Leukotoxic activity of Aggregatibacter actinomycetemcomitans and periodontal attachment loss. PLoS ONE 2014, 9, e104095. [CrossRef]

3. Haubek, D.; Ennibi, O.-K.; Poulsen, K.; Væth, M.; Poulsen, S.; Kilian, M. Risk of Aggressive periodontitis in adolescent carriers of the JP2 clone of Aggregatibacter (Actinobacillus) Aactinomycetemcomitans in Morocco: A prospective longitudinal cohort study. Lancet 2008, 371, 237-242. [CrossRef]

4. Fine, D.H.; Markowitz, K.; Furgang, D.; Fairlie, K.; Ferrandiz, J.; Nasri, C.; McKiernan, M.; Gunsolley, J. Aggregatibacter actinomycetemcomitans and its relationship to initiation of localized aggressive periodontitis: Longitudinal cohort study of initially healthy adolescents. J. Clin. Microbiol. 2007, 45, 3859-3869. [CrossRef] [PubMed]

5. Haubek, D.; Poulsen, K.; Kilian, M. Microevolution and patterns of dissemination of the JP2 clone of Aggregatibacter (Actinobacillus) actinomycetemcomitans. Infect. Immun. 2007, 75, 3080-3088. [CrossRef]

6. Rylev, M.; Kilian, M. Prevalence and distribution of principal periodontal pathogens worldwide. J. Clin. Periodontol. 2008, 35, 346-361. [CrossRef]

7. Haubek, D.; Johansson, A. Pathogenicity of the highly leukotoxic JP2 clone of Aggregatibacter actinomycetemcomitans and its geographic dissemination and role in aggressive periodontitis. J. Oral Microbiol. 2014, 6, 23980. [CrossRef]

8. Elamin, A.; Albandar, J.M.; Poulsen, K.; Ali, R.W.; Bakken, V. Prevalence of Aggregatibacter actinomycetemcomitans in Sudanese patients with aggressive periodontitis: A case-control study. J. Periodontal Res. 2011, 46, 285-291. [CrossRef]

9. Eick, S.; Pietkiewicz, M.; Sculean, A. Oral microbiota in Swiss adolescents. Clin. Oral Investig. 2013, 17, 79-86. [CrossRef]

10. Gajardo, M.; Silva, N.; Gómez, L.; León, R.; Parra, B.; Contreras, A.; Gamonal, J. Prevalence of periodontopathic bacteria in aggressive periodontitis patients in a Chilean population. J. Periodontol. 2005, 76, 289-294. [CrossRef]

11. Macheleidt, A.; Müller, H.-P.; Eger, T.; Putzker, M.; Fuhrmann, A.; Zöller, L. Absence of an especially toxic clone among isolates of Actinobacillus actinomycetemcomitans recovered from army recruits. Clin. Oral Investig. 1999, 3, 161-167. [CrossRef] [PubMed]

12. Okada, M.; Hayashi, F.; Nagasaka, N. Detection of Actinobacillus actinomycetemcomitans and Porphyromonas gingivalis in dental plaque samples from children 2 to 12 years of age. J. Clin. Periodontol. 2000, 27, 763-768. [CrossRef] [PubMed]

13. Mínguez, M.; Pousa, X.; Herrera, D.; Blasi, A.; Sánchez, M.C.; León, R.; Sanz, M. Characterization and serotype distribution of Aggregatibacter actinomycetemcomitans isolated from a population of periodontitis patients in Spain. Arch. Oral Biol. 2014, 59, 1359-1367. [CrossRef] [PubMed]

14. Paolantonio, M.; Di Bonaventura, G.; Di Placido, G.; Tumini, V.; Catamo, G.; Di Donato, A.; Piccolomini, R. Prevalence of Actinobacillus actinomycetemcomitans and clinical conditions in children and adolescents from rural and urban areas of central Italy. J. Clin. Periodontol. 2000, 27, 549-557. [CrossRef]

15. Roman-Torres, C.V.G.; Aquino, D.R.; Cortelli, S.C.; Franco, G.C.N.; dos Santos, J.G.; Corraini, P.; Holzhausen, M.; Diniz, M.G.; Gomez, R.S.; Cortelli, J.R. Prevalence and distribution of serotype-specific genotypes of Aggregatibacter actinomycetemcomitans in chronic periodontitis Brazilian subjects. Arch. Oral Biol. 2010, 55, 242-248. [CrossRef]

16. Sakellari, D.; Katsikari, A.; Slini, T.; Ioannidis, I.; Konstantinidis, A.; Arsenakis, M. Prevalence and distribution of Aggregatibacter actinomycetemcomitans serotypes and the JP2 clone in a Greek population. J. Clin. Periodontol. 2011, 38, 108-114. [CrossRef]

17. Torrungruang, K.; Bandhaya, P.; Likittanasombat, K.; Grittayaphong, C. Relationship between the presence of certain bacterial pathogens and periodontal status of urban Thai adults. J. Periodontol. 2009, 80, 122-129. [CrossRef]

18. Wang, X.; Li, L.; Yang, M.; Geng, Y.; Chen, H.; Xu, Y.; Sun, Y. Prevalence and distribution of Aggregatibacter actinomycetemcomitans and its $\mathrm{CdtB}$ gene in subgingival plaque of Chinese periodontitis patients. BMC Oral Health 2014, 14. [CrossRef] 
19. Ali, R.W.; Velcescu, C.; Jivanescu, M.C.; Lofthus, B.; Skaug, N. Prevalence of 6 putative periodontal pathogens in subgingival plaque samples from Romanian adult periodontitis patients. J. Clin. Periodontol. 1996, 23, 133-139. [CrossRef]

20. Bandhaya, P.; Saraithong, P.; Likittanasombat, K.; Hengprasith, B.; Torrungruang, K. Aggregatibacter actinomycetemcomitans serotypes, the JP2 clone and cytolethal distending toxin genes in a Thai population. J. Clin. Periodontol. 2012, 39, 519-525. [CrossRef]

21. Ellwood, R.P.; Worthington, H.V.; Cullinan, M.P.; Hamlet, S.; Clerehugh, V.; Davies, R. Prevalence of suspected periodontal pathogens identified using ELISA in adolescents of differing ethnic origins. J. Clin. Periodontol. 1997, 24, 141-145. [CrossRef] [PubMed]

22. Belstrøm, D.; Fiehn, N.-E.; Nielsen, C.H.; Kirkby, N.; Twetman, S.; Klepac-Ceraj, V.; Paster, B.J.; Holmstrup, P. Differences in bacterial saliva profile between periodontitis patients and a control cohort. J. Clin. Periodontol. 2014, 41, 104-112. [CrossRef]

23. Claesson, R.; Höglund-Åberg, C.; Haubek, D.; Johansson, A. Age-related prevalence and characteristics of Aggregatibacter actinomycetemcomitans in periodontitis patients living in Sweden. J. Oral Microbiol. 2017, 9, 1334504. [CrossRef] [PubMed]

24. Hölttä, P.; Alaluusua, S.; Saarela, M.; Asikainen, S. Isolation frequency and serotype distribution of Mutans streptococci and Actinobacillus actinomycetemcomitans, and clinical periodontal status in Finnish and Vietnamese children. Eur. J. Oral Sci. 1994, 102, 113-119. [CrossRef] [PubMed]

25. Claesson, R.; Chiang, H.-M.; Lindholm, M.; Åberg, C.H.; Haubek, D.; Johansson, A.; Oscarsson, J. Characterization of Aggregatibacter actinomycetemcomitans serotype b strains with five different, including two novel, leukotoxin promoter structures. Vaccines 2020, 8, 1. [CrossRef] [PubMed]

26. Aarhus i Tal. Aarhus Kommune. Available online: https://ledelsesinformation.aarhuskommune.dk/aarhus-ital/default.aspx?doc=vfs://Global/AARHUS-I-TAL/Hjem.xview (accessed on 4 July 2020).

27. Nørskov-Lauritsen, N.; Claesson, R.; Jensen, A.B.; Åberg, C.H.; Haubek, D. Aggregatibacter actinomycetemcomitans: Clinical significance of a pathobiont subjected to ample changes in classification and nomenclature. Pathogens 2019, 8, 243. [CrossRef] [PubMed]

28. Åberg, C.H.; Kwamin, F.; Claesson, R.; Dahlén, G.; Johansson, A.; Haubek, D. Progression of attachment loss is strongly associated with presence of the JP2 genotype of Aggregatibacter actinomycetemcomitans: A prospective cohort study of a young adolescent population. J. Clin. Periodontol. 2014, 41, 232-241. [CrossRef] [PubMed]

29. Alaluusua, S.; Asikainen, S. Detection and distribution of Actinobacillus actinomycetemcomitans in the primary dentition. J. Periodontol. 1988, 59, 504-507. [CrossRef] [PubMed]

30. DiRienzo, J.M.; Slots, J.; Sixou, M.; Sol, M.A.; Harmon, R.; McKay, T.L. Specific genetic variants of Actinobacillus actinomycetemcomitans correlate with disease and health in a regional population of families with localized juvenile periodontitis. Infect. Immun. 1994, 62, 3058-3065. [CrossRef] [PubMed]

31. Saarela, M.; Asikainen, S.; Alaluusua, S.; Pyhälä, L.; Lai, C.-H.; Jousimies-Somer, H. Frequency and stability of mono-or poly-infection by Actinobacillus actinomycetemcomitans serotypes a, b, c, d or e. Oral Microbiol. Immunol. 1992, 7, 277-279. [CrossRef] [PubMed]

32. Haubek, D.; Ennibi, O.K.; Væth, M.; Poulsen, S.; Poulsen, K. Stability of the JP2 clone of Aggregatibacter actinomycetemcomitans. J. Dent. Res. 2009, 88, 856-860. [CrossRef] [PubMed]

33. Sun, R.; Kittichotirat, W.; Wang, J.; Jan, M.; Chen, W.; Asikainen, S.; Bumgarner, R.; Chen, C. Genomic stability of Aggregatibacter actinomycetemcomitans during persistent oral infection in human. PLoS ONE 2013, 8. [CrossRef] [PubMed]

34. Haffajee, A.D.; Socransky, S.S. Microbial etiological agents of destructive periodontal diseases. Periodontol. 2000 1994, 5, 78-111. [CrossRef] [PubMed]

35. Danmarks Statistik. Indvandrere og efterkommere-Danmarks Statistik. Available online: https://www.dst. $\mathrm{dk} / \mathrm{da} /$ Statistik/emner/befolkning-og-valg/indvandrere-og-efterkommere/indvandrere-og-efterkommere (accessed on 18 August 2020).

36. Collins, J.R.; Chinea, S.; Cuello, R.J.; Florian, A.P.; Palma, P.; Ambrosio, N.; Marín, M.J.; Figuero, E.; Herrera, D. Subgingival microbiological profile of periodontitis patients in Dominican republic. Acta Odontol. Latinoam. 2019, 32, 36.

37. Psoter, W.J.; Ge, Y.; Russell, S.L.; Chen, Z.; Katz, R.V.; Jean-Charles, G.; Li, Y. PCR detection of Streptococcus mutans and Aggregatibacter actinomycetemcomitans in dental plaque samples from Haitian adolescents. Clin. Oral Investig. 2011, 15, 461. [CrossRef] 
38. Jensen, A.B.; Ennibi, O.K.; Ismaili, Z.; Poulsen, K.; Haubek, D. The JP2 Genotype of Aggregatibacter actinomycetemcomitans and marginal periodontitis in the mixed dentition. J. Clin. Periodontol. 2016, 43, 19. [CrossRef]

39. Ennibi, O.K.; Claesson, R.; Akkaoui, S.; Reddahi, S.; Kwamin, F.; Haubek, D.; Johansson, A. High salivary levels of JP2 genotype of Aggregatibacter actinomycetemcomitans is associated with clinical attachment loss in Moroccan adolescents. Clin. Exp. Dent. Res. 2019, 5, 44. [CrossRef]

40. Marin, M.; Ambrosio, N.; Herrera, D.; Sanz, M.; Figuero, E. Validation of a Multiplex qPCR assay for the identification and quantification of Aggregatibacter actinomycetemcomitans and Porphyromonas gingivalis: In vitro and subgingival plaque samples. Arch. Oral Biol. 2018, 88, 47. [CrossRef]

41. Orrù, G.; Marini, M.F.; Ciusa, M.L.; Isola, D.; Cotti, M.; Baldoni, M.; Piras, V.; Pisano, E.; Montaldo, C. Usefulness of real time PCR for the differentiation and quantification of 652 and JP2 Actinobacillus actinomycetemcomitans genotypes in dental plaque and saliva. BMC Infect. Dis. 2006, 6. [CrossRef]

42. Chapple, I.L.C.; Mealey, B.L.; Van Dyke, T.E.; Bartold, P.M.; Dommisch, H.; Eickholz, P.; Geisinger, M.L.; Genco, R.J.; Glogauer, M.; Goldstein, M.; et al. Periodontal health and gingival diseases and conditions on an intact and a reduced periodontium: Consensus report of workgroup 1 of the 2017 world workshop on the classification of periodontal and peri-implant diseases and conditions. J. Periodontol. 2018, 89, S74. [CrossRef]

43. Tonetti, M.S.; Greenwell, H.; Kornman, K.S. Staging and grading of periodontitis: Framework and Proposal of a new classification and case definition. J. Periodontol. 2018, 89, S159. [CrossRef] [PubMed]

44. Papapanou, P.N.; Sanz, M.; Buduneli, N.; Dietrich, T.; Feres, M.; Fine, D.H.; Flemmig, T.F.; Garcia, R.; Giannobile, W.V.; Graziani, F.; et al. Periodontitis: Consensus report of workgroup 2 of the 2017 world workshop on the classification of periodontal and peri-implant diseases and conditions. J. Clin. Periodontol. 2018, 45, S162. [CrossRef] [PubMed]

45. Marin, M.J.; Figuero, E.; Herrera, D.; Sanz, M. Quantitative analysis of periodontal pathogens using real-time polymerase chain reaction (PCR). In Methods in Molecular Biology (Clifton, N.J.); Springer: Berlin/Heidelberg, Germany, 2017; Volume 1537. [CrossRef]

46. SciPy. SciPy v1.3.0 Reference Guide. Available online: https://docs.scipy.org/doc/scipy-1.3.0/reference/ (accessed on 8 July 2019).

Publisher's Note: MDPI stays neutral with regard to jurisdictional claims in published maps and institutional affiliations.

(C) 2020 by the authors. Licensee MDPI, Basel, Switzerland. This article is an open access article distributed under the terms and conditions of the Creative Commons Attribution (CC BY) license (http://creativecommons.org/licenses/by/4.0/). 